\title{
The British partnership phenomenon: a ten year review
}

This article presents a detailed review of the vast partnership literature which has emerged in the UK between 1998 and 2008. It begins by examining definitions of partnership, and suggests that while academic definitions are vague, practitioner definitions tend to conflate partnership processes with partnership outcomes. An alternative definition based upon processes and practices is offered. This is followed by a review of the conceptual advocates/critics debate, and the key themes of empirical partnership studies. It is proposed that while recent empirical evidence identifies a variety of outcomes and presents various typologies of partnership, there is an absence

of debates on typologies in the literature. The article then identifies several limitations of the existing literature including ideological positions, a lack of sensitivity to context and to different types of partnership, and a focus on outcomes. The article concludes by suggesting avenues for future partnership research. 


\section{The British partnership phenomenon: a ten year review}

"The concept of partnership has become the defining feature of the 'new' industrial relations settlement for the Millennium" (Stuart and Martinez-Lucio, 2004b, 410).

\section{Introduction}

In 1998 Ackers and Payne identified a new HRM trend, partnership, which promised to bring unions back into the heart of the employment relationship (Ackers and Payne, 1998). Partnership was also at the core of the 1998 'Fairness at Work' agenda set out by the Blair government (DTI, 1998), and the end of Blair's ten year term in office provides an opportune time to take stock of the voluminous partnership literature which has emerged. Though the UK partnership debate may be a relatively recent phenomenon, the topic has attracted a significant amount of research attention since 1998, including regular special streams at employment relations conferences and over 40 journal publications. To do justice to the vast literature available and to remain sensitive to issues of institutional setting, as well as for reasons of brevity, this paper focuses upon contributions from the UK. The purpose of the article is to examine the literature to date, evaluate the key debates and controversies, and make some suggestions as to what the future may hold for the partnership debate. The paper begins by examining definitions of partnership. This is followed by an overview of the conceptual advocates/critics debate, and the key themes of empirical partnership studies. The paper then highlights several limitations of the existing British literature, and concludes by suggesting a need to understand more about the process of partnership, to clarify the meaning and expectations of partnership, and stresses the importance of evaluating partnership in context. 


\section{What is 'partnership'?}

"The term partnership has become too diffuse to carry much meaning" (Oxenbridge and Brown, 2004b, 389).

Since the early 1990s partnership has attracted an enormous amount of attention from the New Labour government (DTI, 1998), the Trade Union Congress (TUC, 1999), most of the major British trade unions, as well as Acas and The Work Foundation (Acas, 2003). Though the partnership concept has attracted a rich research literature, definitions of partnership remain a matter for debate (Ackers et.al, 2004; Ackers and Payne, 1998; Dietz, 2004; Guest and Peccei, 2001; Stuart and Martinez-Lucio, 2004a). As a result of the "inherent ambiguity" (Bacon and Storey, 2000, 409), partnership has been described as "an idea with which almost anyone can agree, without having any clear idea what they are agreeing about" (Guest and Peccei, 2001, 207). In reality, however, the concept has attracted significant controversy and support is far from universal. Indeed an element of ambivalence has been evident within the union movement (e.g. RMT and ASLEF), employer bodies (e.g. CBI and IOD) and employers (e.g. anti-union campaigns) (Gall, 2004, IoD, 2002; Undy, 1999). In part this may reflect the lack of a common definition.

Academic definitions centre around the idea of "co-operation for mutual gain" and "reciprocity" (Martinez-Lucio and Stuart, 2002). For Gall (2004) the idea of 'mutualism' - where a successful employer is able to benefit all stakeholders involved - is a defining feature. Guest and Peccei (2001) also suggest that trust and mutuality are the key components of a genuine partnership agreement. Rhetorically at least, partnership 
appears to be hinged upon the proposition that, for employers, it can be both economically effective and ethically responsible to co-operate with unions and employees on issues of strategic organisational change (Stuart and Martinez-Lucio, 2004). Of course the notion of joint working and workplace collaboration is not new (Stuart and Martinez-Lucio, 2004); rather the idea of 'enlightened' consensual relations draws from a long history of modernisation in British IR (Ackers et.al, 2004; Marchington, 1998). It is also worth noting that though the meaning of partnership in the UK is quite different to traditional continental notions of 'social partnership' associated with the more regulatory European Social Model, there are clear similarities between the EU notion of a 'new' European Social Model (as set out in the EC Green Paper Partnership for a New Organisation of Work) and the British notion of partnership (Sisson, 1999).

It has been suggested that a useful definition "should describe a set of organisational characteristics and practices that, firstly, do justice to the idea of managing employment relations in a 'partnership' manner and secondly, are readily observable in order to verify a genuine example in practice" (Dietz, 2004, 4; see also Guest and Peccei, 2001). To this end, more practical definitions are offered by the TUC and IPA.

\section{[FIGURE 1 ABOUT HERE]}

While the IPA definition is open enough to allow for the possibility of partnership in nonunion contexts, the TUC believe trade union presence is essential to partnership arguing that "in companies without unions...consultation always risks being a sham" 
(TUC, 2002, 5). The two models also agree on the need to balance flexibility with employment security, and the desirability of positive employee outcomes although these are defined slightly differently, with the IPA focusing on 'sharing success', whereas the TUC prefers the broader notion of' 'improving the quality of working life' (TUC, 1999, 13). Both include outcomes as part of their definition of partnership, and it is proposed here that it is important to avoid conflating partnership practices and processes with employment relations outcomes. Employment relations outcomes (such as employment security or adding value) are better thought of as aspirations which need to be explored empirically, but do not constitute an integral component of partnership process per se. Partnership may concern an attempt to achieve these outcomes, irrespective of whether or not they are achieved.

A more useful definition would identify practices and processes (but not outcomes) associated with partnership. In terms of practices, employee voice is central to all definitions and this may involve a mix of direct participation, representative participation and financial involvement. However, most policy and organisational definitions suggest it is representative participation which is the bedrock of partnership, with or without trade unions, and this is also implicit in most academic research. At the centre of the process of partnership are issues of decision making and actor relationships. Partnership decision making is typically described as a 'joint problem solving approach', characterised by early consultation and affording some influence over decision making but not necessarily joint decision making. Actor relationships are said to require trust and openness, mutual legitimacy and a commitment to business success, and as such 
the values and behaviour of organisational actors are crucial. Inevitably, there is likely to be some variety within this general framework, but it is proposed that these are the practices and processes which underpin a prima facie case of partnership and are likely to be mutually reinforcing.

\section{Ideological debates: nirvana or dead end?}

Most commentators acknowledge a polarised conceptual debate in the early contributions between 'advocates and critics', regarding the potential of partnership as a union revitalisation strategy, and the extent to which the mutual gains are actually realisable (Guest et.al, 2008; Martinez-Lucio and Stuart, 2004; Oxenbridge and Brown, 2004a, 2004b; Stuart and Martinez-Lucio, 2004b; Terry and Smith, 2003). Though excellent reviews of this debate are captured elsewhere (Stuart and Martinez-Lucio, 2004; Tailby and Winchester, 2005), a brief review is deemed necessary in order for the evolution of British partnership research over the last decade to be fully understood.

For advocates partnership may offer an opportunity for unions to extend their representative capacity. Ackers and Payne $(1998,531,546)$ argue that partnership "offers British unions a strategy that is not only capable of moving with the times and accommodating new political developments, but also allowing them a hand in shaping their own destiny" and "provides an opportunity for British unions to return from political and economic exile". Advocates are also attracted by the idea of 'mutual gains' bargaining over employment security, flexibility, development and involvement (Kochan and Osterman, 1994). It is suggested that employers may benefit from a new cadre of representatives, improved relations with unions, and assistance with the facilitation of 
change. In turn unions may benefit from increased influence, greater access to information, job security and inter-union co-operation (Marchington, 1998). Employees are also said to benefit from greater job security, training, quality jobs, good communication and more effective voice (Guest and Peccei, 2001; Kochan and Osterman, 1994; Knell, 1999).

On the other hand, critics question the coherence of the partnership model, and point to the risks of adopting such an approach (Claydon, 1998; Danford et.al, 2005a; Kelly, 1996; Taylor and Ramsey, 1998). Their primary concern is the extent to which partnership incorporates trade unions and may lead to compliant unions thus limiting the ability of unions to attract members (Kelly, 1996; Marks et.al, 1998; Taylor and Ramsey, 1998). It has been argued that some employers may view partnership as another union 'Trojan horse' and express a preference for free labour markets and individualisation of the employment relationship (Claydon, 1998). Indeed, WERS04 revealed that $77 \%$ managers agreed that they would rather deal with employees directly rather than through trade unions (Kersely et.al, 2006). Managers may also be concerned that partnership may slow down decision-making, incur extra costs, and challenge their managerial prerogative. Critics argue that partnership may simply represent a pragmatic management decision rather than evidence of a long-term commitment to working with unions, as managers decide to 'involve' unions but only within strictly defined parameters (Ackers et.al, 2004; Bacon, 2001). In other words, management will always be pragmatic in attempts to identify 'what works' (Edwards, 2003). 
The most vocal case against partnership has been expressed by Kelly who defines the debate in terms of a choice between militancy and moderation (1996, 87). For Kelly, union militancy is a preferable option in light of what he perceives to be the growing hostility of employers to any form of unionism, the beneficial consequences of industrial action, the meagre consequences of moderation, and the continuing antagonism of interests between workers and employers. He concludes that "it is difficult, if not impossible, to achieve a partnership with a party who would prefer that you didn't' exist, the growth of employer hostility is a major objection to the case for moderation" (Kelly, 1996, 88). Critics also express fundamental concerns regarding the British business environment and structure of corporate governance which focuses upon short-term performance, arguably meaning there is less incentive to engage in long-term partnerships (Ackers et.al, 2004; Deakin et.al, 2004; Heery, 2002; Suff and Williams, 2004) and the possibility the employer may renege on promises at any time, given the voluntarist framework of minimal juridification (see also Haynes and Allen, 2001). In short, the early partnership debate was starkly polarised between the optimists and the pessimists (see Figure 2).

[FIGURE 2 ABOUT HERE] 


\section{Empirical evidence}

The past decade has also seen a large quantity of empirical studies on partnership, most of which are qualitative case studies (see Figure 3).

[Insert Figure 3 about here]

Perhaps because of the bleak prognosis of the early commentaries on the future of unions in the UK (Howell, 1999; Metcalf, 2004; Ross and Martin, 1999), many of the early studies focus upon trade union representative capacity outcomes (see for example Haynes and Allen, 2001; Heaton et.al, 2000; Heery et.al, 2004; Martinez-Lucio and Stuart, 2002; McBride and Stirling, 2002; Wills, 2004; Wray, 2004). A second stream of literature focuses on the extent to which partnership delivers mutual or uneven benefits to employers, unions, and employees (see for example Badigannavar and Kelly; Danford et.al, 2004; 2005; Johnstone et.al, 2004; Kelly, 2004; Kelly, 2004b; Oxenbridge and Brown, 2004b; Richardson et.al, 2004; 2005; Suff and Williams, 2004). More positive studies reveal stronger workplace union organisation, more effective consultation, improved management-union relationships, access to senior decision makers in the organisation, and greater employer and employee support for unions (Haynes and Allen, 2001; Oxenbridge and Brown, 2004a; Samuels, 2005; Wills, 2004). Critical studies, however, suggest difficulties demonstrating union effectiveness, greater distance between unions and their members, work intensification, job insecurity, and labour outcomes no better than non-partnership firms (Kelly, 2004; Richardson et.al, 2004; Tailby et.al, 2004). Much of the interest in mutual gains appears to relate to an 
article by Guest and Peccei (2001) on the 'balance of advantage'. This is where ideological differences emerges. While radicals seek gains which flow equally to employers, employees and unions, pluralists take the view that the aim is one of levelling the playing field, and having sufficient influence to make a difference.

The more recent literature suggests that the initial advocates/critics debates were deterministic, and that partnership may not hold any single consequence, but depends upon the various conditions such as the underlying management and union strategies, rationale for partnership, and the way in which it has been implemented (Heery, 2002; Heery et.al, 2004; Samuel, 2005; Wills, 2004). From the literature various distinctions can be drawn including formal $v$ informal, union $v$ non-union, public sector $v$ private sector, as well as the variety of routes to partnership. This has led to various typologies of partnership emerging in recent studies (Deakin et.al, 2004; Kelly, 2004a; MartinezLucio and Stuart, 2004; Oxenbridge and Brown, 2004; Wray, 2004).

[Insert Figure 4 about here]

The typologies literature suggests that there must be specific conditions under which a robust partnership is likely to emerge. This reflects the arguments of Kochan and Osterman (1994) that partnership must be sufficiently institutionalised if it is to be enhancing or effective. It also suggests a need to understand the different types of partnership that are possible, and to avoid asserting that partnership necessarily leads 
to a specific outcome (Haynes and Allen, 2001; Samuels, 2005; Wills, 2004). As Martinez-Lucio and Stuart state:

"Accounts of partnership as a panacea for the future of employment relations are too simplistic, but so too are those that crudely conceptualise partnership as the latest management weapon for incorporating trade unions" (MartinezLucio and Stuart, 2004, 421).

\section{Limitations of the existing literature}

Though British partnership debate now commands an extensive and commendable literature, it is proposed that ideological, contextual, and methodological limitations can be identified. These limitations are discussed in turn.

\section{Ideology}

Firstly, there is a strong ideological dimension to partnership (McBride and Stirling, 2002). Views on partnership are inextricably linked to industrial relations frames of reference (Fox, 1974), and as such partnership is much more likely to be acceptable to those holding a unitarist or pluralist viewpoint. For radicals, the institutional framework without sectoral/industrial bargaining, combined with short-termist corporate governance - inevitably leaves little scope for partnership (Waddington, 2003). In addition, even although critics report some positive findings in their studies, these are sometimes overlooked in the conclusions of the overtly critical commentators. Accordingly, many of the most pessimistic studies (e.g. Kelly, 2004; Tailby et.al, 2004) are written from within the radical IR tradition which opposes any form of class collaboration. On the other hand, IR pluralists (e.g. Oxenbridge and Brown, 2004; Samuel 2007) are more divided 
and uncertain, with outcomes believed to be contingent upon an appropriate and supportive macro and micro-level framework. Martinez-Lucio and Stuart (2005), for example, highlight the importance of risk and related exogenous and endogenous forces in understanding the dynamics of different forms of labour management partnership relations, and how they develop over time.

\section{Context}

Analysis of partnership should examine the context of the agreement as well as the relationships surrounding the negotiations (Jenkins; 2007, 2008; Johnstone, 2009; McBride and Stirling, 2002), though this is not apparent in some of the most critical studies (e.g. Kelly, 2004). As Marchington et.al $(1994,890)$ argue in their studies of El, it is important to contextualise actor attitudes within the competitive and strategic environment in which businesses operate. They argue that there is a need to 'ground' studies of employee involvement in context, and the same is true for studies of partnership. For example if only bad news is being delivered through the partnership infrastructure this could very possibly lead to negative attitudes towards partnership itself. Conversely, positive attitudes towards partnership could be symptomatic of a feel good factor within the organisation because of recent good news such as a large pay rise. Workers' prior experiences of participation, management's approach to employment relations, and the recent and future performance of the organisation are all likely to be important (Marchington et.al, 1992, 1994). This leads to difficulties interpreting and comparing evaluations derived from both buoyant sectors and those in decline, with different industrial relations traditions and product/labour market conditions 
(Johnstone et.al, 2004). There is the possibility that partnership is likely to be successful in older industry sectors, with a history of unionisation, and buoyant sectors (Kelly, 2004a; Heery, 2002; Oxenbridge and Brown, 2004b). In particular, a clear distinction must be made between partnership in the public sector, where union density is often high, combined with strong state protection and insulation from market forces, compared to the private sector, where union density is often low, a tradition of unionism may be less entrenched, and market competition may be high.

\section{Methodology}

There are also several methodological issues. In particular, there is lack of data regarding worker responses to partnership (Suff and Williams, 2004, 33). As Ackers et.al (2004) state, "The attitudes and experiences of ordinary employees are central to deciding how successful a system of partnership or participation is", given that managers and trade union criteria for 'effective' voice are likely to be quite different from those of 'ordinary workers' (Ackers et.al, 2004, 56). Surprisingly, there has been a lack of emphasis on employee responses to partnership (notable exceptions include Richardson et.al, 2004). Rather, interviewees are typically trade union officials and managers, and few partnership studies have really engaged with debates on what workers want (see for example Bryson and Freeman, 2006). In many ways this reflects the tendency of some industrial relations research to conflate the institutional interests of trade unions with the interests of employees, based on an assumption that what is good for the union must also be good for workers. However, employee attitudes and experiences should be a shaping factor in the success or failure of partnership. 
There is also a lack of comparative case study research. It is likely that comparative cases could assist with the process of 'theoretical generalisation' from the cases (Yin, 2003). Admittedly, the conduct of comparative case studies is not helped by the fact that it is difficult - though not impossible - to identify a credible prima facie instance of partnership. This leads to the situation whereby Kelly (2004a) identifies Abbey National as a non-partnership organisation, whereas the IPA $(2004,1)$ claim they have a formal partnership agreement. Clearly, researchers need to justify why they believe the case investigated constitutes a prima facie instance of partnership.

More generally, Kelly has criticised the lack of methodological rigour in some of the case study research commenting how, "The level of methodological rigour in the empirical research is sometimes poor. There are numerous widely cited case studies of partnership firms that are often uncritical and journalistic in tone, excessively reliant on the views of a few partisan informants, and seriously under-theorised" (Kelly, 2004a, 270). While an important point, clearly the need for methodologically rigorous research applies equally to the conduct of quantitative partnership studies as well, for it is not only case study research that is problematic. The TUC (2002) for example claim that evidence from WERS98 suggests that partnership organisations make fewer people redundant, have shorter average working hours and rarely declare compulsory redundancies. This is a somewhat dubious analysis given that WERS98 does not distinguish between partnership and non-partnership organisations, or indeed make any reference to partnership whatsoever. Moreover, much of the literature is limited to 
snapshot case studies at a particular point in time. Clearly, this is not ideal given that partnership is a dynamic process evolving over time, and like any relationship takes time to evolve.

\section{Varieties of partnership}

A related issue concerns sensitivity to different types of partnership agreement as "Partnership is a loose word for many shades of the employment relationship" (Ackers et.al, 2004, 17), and distinctions can be made in terms of several variables. For example, there has been a focus on formalised agreements (with the exception of Oxenbridge and Brown, 2004), although some research has begun to make distinctions between 'de jure' and 'de facto' partnerships (Ackers et.al, 2004). Oxenbridge and Brown (2004b) identify three broad categories of relationship in terms of formality: formal partnerships with explicit agreements; informal partnerships where the term is widely used, and cooperative relationships which may not actually be described by the parties as partnership. There are also different routes to - and rationales for partnership (see for example Ackers et.al, 2004; also Martinez-Lucio and Stuart, 2005).

There has also been a focus on partnerships between unions and management (Ackers et.al 2004, 56; Stuart and Martinez-Lucio, 2004b, 418), and the same bias is evident in wider discussions of voice which have also tended to be union centred. Non union workplaces are crudely assumed to have no HRM and no IR, and often non-union voice is dismissed as inferior to union voice without reference to empirical evidence (Haynes, 2005). Again, where non-union voice structures do exist they are assumed to be merely cosmetic devices lacking the necessary power and authority to be effective (Terry, 
1999), even although evidence on the efficacy of representation in non-union settings is mixed (Bryson, 2004; Dundon and Rollinson, 2004; Gollan, 2007). In addition, while radicals may view voice as a means to an end (Hyman, 1978; 2004), pluralists tend to perceive intrinsic value in the process of voice itself (Clegg, 1975). This relates to the greatest limitation of the British partnership literature: the focus on outcomes.

\section{[FIGURE 5 ABOUT HERE]}

\section{Focus on outcomes}

The tendency to focus on outcomes is odd given that partnership outcomes are notoriously difficult to quantify (Roper, 2000), and because partnership is about much more than just outcomes. As Stuart and Martinez-Lucio make clear:

"Partnership is not just about outcomes, or its potential for trade unions...partnership is a development that represents the emergence of a new approach to employment relations that attempts to reconfigure the form and content of management-union relations" (Stuart and Martinez-Lucio, 2004, 11).

In other words, partnership can be viewed more broadly as an attempt to reconfigure employment relations in light of the demise of old style joint regulation (Terry, 2003). Dietz also suggests that it not just the outcome which is important but also more subtle issues such as the way issues have been handled. For example in relation to job losses:

"One need not express surprise when large scale redundancies take place under partnership. This issue is how they are agreed upon and handled" (Dietz, 2004, 9) 
Partnership is also about subtle changes in attitudes and behaviours, which may not always be apparent if a narrow outcome focus is taken, requiring more attention to "internal behaviour transformations and attitudinal improvements" (Dietz, 2004, 7; c.f. Walton and McKersie, 1965). Such factors would inevitably be missed by studies such as Kelly (2004a) where selected labour outcomes are used to 'measure' the success of partnership. A similar sentiment is expressed by Wray who explains how in his research, "It quickly became clear that a full assessment of the outcome would be impossible without a comprehensive understanding of the nuances shaping the process of negotiation" (Wray, 2004, 193).

It is not only the focus on outcomes which gives cause for concern, but also the way the outcomes of partnership have been evaluated and judged. In particular there is a lack of agreement regarding what partnership is actually expected to achieve, especially if the measurements for success are set unrealistically high. This has led to a situation whereby: "The expectations (both in terms of hopes and fears) generate by the term [partnership] means that it has become all too easy to set it up as a straw debate with aim of knocking it down" (Stuart and Martinez-Lucio, 2004b, 22). Consequently, outcomes are too easily offset against unrealistic announcements and agreements (e.g. increasing transparency, enhancing training and development, creating a better quality of working life), or other equally ambitious aims such as the renaissance of the union movement. These far exceed the expectations of even optimists like Ackers and Payne (1998). Much depends on how 'successful' partnership is defined and what it is expected to achieve, but it seems unrealistic that long-term partnerships will lead to 
harmonious, consensual and conflict-free IR (Terry and Smith, 2003). After all, the employment relationship consists of a blend of shared and contrary interests which inevitably lead to periods of both co-operation and conflict (Bacon, 2001). It also seems unrealistic to suggest that partnership will lead to 'mutual gains' in the purest sense of the term, with gains flowing equally and harmoniously to all parties; indeed it is difficult to imagine what such a situation would look like.

Most commentators do agree, however, that it essential to examine process in addition to outcomes if a more holistic understanding is to be achieved, as the following array of quotes illustrate:

"Good processes matter more than good institutions" (Guest and Peccei, 1998, 9).

"Although there exists a wealth of published material governing the breadth and depth of participatory practices in UK workplaces, we have much less understanding of participation as a process" (Danford et.al, 2005, 613). 
"The study of partnership requires an approach that is sensitive to internal processes of decision-making, and the rationales that underpin the elaboration of strategies regarding work" (Martinez-Lucio and Stuart, 2004, 421).

"Need to understand more about the substance of the relationships forged as a measure of robustness as opposed to the formality of the agreement" (Oxenbridge and Brown, 2004c, 143).

Curiously, despite acknowledgement that process is important, and that without it only a partial view of partnership can be achieved, few British studies have explicitly focused on understanding the process as well as the outcomes, in order to achieve a more holistic understanding.

\section{Conclusions}

There are three main implications from this paper. Firstly, it is important to examine partnership in context, at both the macro and micro levels. Secondly, there is a need to understand more about the process of partnership. Thirdly, there is a need to clarify the meaning and expectations of partnership before any attempt can be made to judge the outcomes.

Partnership in context

It is a focus on partnership at the micro workplace level which has constituted the bulk of UK research in the last decade. Most of the research is case study based, and therefore demonstrates some sensitivity to contextual factors. However, given that it is possible that an organisation could achieve good working relationships and business 
outcomes without partnership and vice versa, a lack of a full contextual understanding could hinder analysis of partnership. Indeed, it is difficult to isolate ER/partnership outcomes from broader contextual issues such as corporate strategy and labour market conditions. This reflects the broader challenges of linking particular HR activities to specific organisational outcomes, an issue discussed at length in the HR literature (Marchington and Wilkinson, 2008).

There is also a need to locate partnership studies within the broader macro-level context of British IR including union decline and less jointly regulated employment relations. Most worryingly perhaps is that despite government endorsement, there has been a lack of enthusiasm from employer bodies such as the CBI, IOD and, to a lesser extent, the CIPD. In addition, after a decade of endorsing workplace partnership there is a lack of clarity as to whether the appetite for partnership by the TUC and individual trade unions has also waned. Clearly, levels of employer and employee support for unions are central to the success or otherwise of union-management forms of partnership.

\section{Partnership as process}

Despite the agreement that process is important, much of the British partnership debate has focussed on hard-to-measure outcomes rather than on understanding process (Terry and Smith, 2003). It is proposed that two particular aspects of process are likely to be instructive. There is a need to be more sensitive to the mechanisms of voice, and 
to the ways in which partnership mechanisms influence behaviour and outcomes, for example in terms of decision making processes. As Dietz states:

"The litmus test for all partnerships - unionised or not - is the quality of the joint problem solving processes...giving significant influence to employees over organisational decision-making early in the process, and in delivering regular, acceptable mutual gains for all parties" (Dietz et.al, 2005, 302).

Sensitivity must also be paid to the presence or absence of partnership 'behaviours' in the employer-union relationship, such as the level of trust between actors and the way they interact and this is really what is distinctive about partnership. Oxenbridge and Brown (2004a) suggest that a high trust relationship is likely to be characterised by a central and legitimised role for workplace representatives, trade union involvement at the earliest stage of management decision-making, explicit or implicit acknowledgement that each party benefits from the relationship, openness in dealings between the parties, and commitment to the relationship from managers at all levels of the organisation (Oxenbridge and Brown, 2004b, 156). It is important therefore to "look beyond the superficial terminology to the relationships that underlie it...the intentions that lie behind them" (Oxenbridge and Brown, 2004b, 157).

Inspiration for future research in Britain may be taken from contributions from other liberal market economies including Ireland and the United States (Hall and Soskice, 2001), which examine the complex dynamics and processes of partnership. Such studies attempt to understand more about the preconditions for effective partnership, and the particular circumstances in which 'mutual gains' may be realised. Kochan and 
Osterman suggested in 1994, several years prior to the mushrooming of the UK partnership debate, the need for the integration of partnership at a strategic, functional/HR policy level, and workplace level (Kochan and Osterman, 1994). They make clear that rhetoric alone will not deliver effective outcomes or mutual gains, and indicate a range of preconditions ranging from job security, training and employee selection, through to management commitment and supportive business strategies. In a more recent review of the US context, Kochan et.al (2008) identify further enablers of partnership including a perceived need to change the status quo, investment in the skills and capabilities of actors, changes in the roles and leadership styles of managers and unionists at all levels, new structures, overcoming resistance, and the achievement of tangible valued sustained results over time. Evidence from the Republic of Ireland similarly stresses the importance of institutionalising partnership at all levels, and in particular avoiding a partnership which remains the preserve of an elite corps at the apex of the organisation, disconnected from the grassroots (Geary and Roche, 2002).

\section{Meaning and expectations of partnership}

There is a need to clarify the meaning and expectations of partnership before any attempt can be made to judge the outcomes. Definitions such as 'mutuality', 'reciprocity' are simply too vague. While they suggest a relationship between two parties, and the notion of an exchange where each party gains something, this reveals very little about the quality of the employment relationship; indeed even a Dickensian sweatshop could be described in such terms. 'Co-operative employment relations' is also ambiguous, as a co-operative relationship to one person could be perceived as co-option by another 
(Dietz, 2004). A more useful definition would include identifiable practices (such as employee and especially representative participation) with specific processes, such as early consultation and a 'joint problem solving approach' to decision making. Relationships based on trust, mutual legitimacy, and commitment to business success are also central. It is also important to draw an analytical distinction between partnership (defined as a combination of practices and processes), and employment relations outcomes which ought to be considered separately. For pluralists, what really matters is the extent to which partnership delivers some benefits to employees, as well as wider benefits to the economy and society as a whole. There is a need to reconsider the benchmarks for success, and to pay more attention to the expectations and perceptions of the actors themselves, and not just those of academic theorists.

\section{The future of partnership research}

After a decade of research, considerable scope for further studies into partnership remains.

1. There is a need for more longitudinal research. Currently, most British case study research offers only a snapshot of partnership at a particular point in time in the organisations studied. However, it would be valuable to observe a partnership relationship over time, and longitudinal research could trace shifts in the partnership process and actor experiences. Of course organisations may not wish to participate in research over an extended period of time, and there are also possible concerns regarding the most appropriate times to conduct such studies (Ichniowski et.al, 1996). Nevertheless, longitudinal studies such as those 
into employee involvement in the UK (Marchington et.al, 1992; Marchington et.al, 2001) are extremely useful in tracing patterns and developments over time. Indeed, more longitudinal studies in British industrial relations research would be welcome in general, given the fields established tradition of case study research.

2. Comparative 'firm-in-sector' case studies (Smith et.al, 1990, would complement the single case studies which characterise the British literature. These could explore the experiences of partnership in various sectoral contexts. Such studies would enable comparisons to be made between organisations operating within similar constraints such as product and labour market conditions. A useful framework would be to explore prima facie union and non-union partnerships, with employment relations in union and non-union organisations without partnership in the same sector.

3. There is a need to redefine the debate by evaluating the experiences of stakeholders other than trade unions, and to go beyond the questionable emphasis on trade union renewal. Studies could also aim to understand more about contemporary worker views and avoid relying on trade unionists as proxies of employee views.

4. There is a need to know more about partnership as a process, rather than just the content of agreements, or the raw outcomes, and to avoid conflating issues of process and outcome.

5. Given the complexity of partnership, there is also a need to understand more about the context, motives and drivers for partnership. 
6. There is also the need to further explore the disparate typologies and models which have emerged to advance understanding. Currently researchers have devised a range of expressions to capture what they believe to represent positive and negative partnership arrangements, and it would be useful to synthesise these into a common acceptable model, irrespective of ideological and methodological differences.

7. The British debate could perhaps benefit from increasing attention to developments in the wider partnership debates internationally, in order to make sense of issues of macro political and socio-economic context. Interesting comparisons can be made with debates in the USA and Ireland, as well as Australia and New Zealand.

8. Lastly, the majority of British workplaces no longer recognise trade unions, and new pluralism is characterised by a mix of union and non-union bodies, formal and informal structures, and a range of consultation, negotiation and bargaining arrangements. More research is therefore needed into the characteristics and efficacy of non-union partnership arrangements. 


\section{References}

ACAS (2003) Acas Annual Report and Resource Accounts. London: Acas.

Ackers, P. \& Payne, J. (1998). British trade unions and social partnership: rhetoric, reality and strategy, The International Journal of Human Resource Management, 9, 3, 529-549.

Ackers, P., Marchington, M., Wilkinson, A. \& Dundon, T. (2004). Partnership and voice, with or without trade unions: changing UK management approaches to organisational participation. In M. Stuart \& M. Martinez-Lucio (Eds), Partnership and Modernisation in Employment Relations. London, Routledge..

Bacon, N. (2001) 'Employee Relations' in T. Redman and A. Wilkinson (eds). Contemporary Human Resource Management. London: FT Prentice Hall, pp. 193-214.

Bacon, N. and Storey, J. (2000) 'New Employee Relations Strategies in Britain: Towards Individualism or Partnership?', British Journal of Industrial Relations, 38 (3), 407-427.

Badigannavar, V.F. and Kelly, J.F. (2004) Labour-management partnership in the UK public sector, in J. Kelly and P. Willman, Union organization and activity. London: Routledge.

Badigannavar, V. F. and Kelly, J. F. (2005) 'Labour-management partnership in the non-union retail sector', International Journal of Human Resource Management, 16 (8), 1529-1544.

Beale, D. (2004) The promotion and prospects of partnership at the Inland Revenue, employer and union hand in hand? In M. Stuart and M. Martinez-Lucio (eds) Partnership and modernisation in employment relations, London, Routledge, pp.216-246.

Bryson, A. and Freeman, R (2006) What do British workers want? CEP Discussion Paper 731, July. London: LSE.

Bryson, A. (2004) 'Managerial Responsiveness to Union and Nonunion Worker Voice in Britain', Industrial Relations, 43 (1), 213-241.

Claydon, T. (1998) Problematising partnership: the prospects for a co-operative bargaining agenda, in P. Sparrow and M. Marchington, Human Resource Management: the New Agenda. London: Pitman, pp. 180-191.

Clegg, H. (1975) Pluralism in industrial relations, British Journal of Industrial Relations, 13(3), 309-316.

Danford A., Richardson, M., Stewart, P., Tailby, S. and Upchurch, M. (2004) 'High Performance Work Systems and Workplace Partnership: a case study of aerospace workers', New Technology, Work and Employment, 19 (1), pp. 14-29

Danford, A., Richardson, M., Stewart, P., Tailby, S. and Upchurch, M. (2005) 'Workplace partnership and employee voice in the UK: comparative case studies of union strategy and worker experience', Economic and Industrial Democracy, 26 (4), 593-620. 
Danford, A. Richardson, M. Stewart, P. Tailby, S. And Upchurch, M. (2008) 'Partnership, high performance work systems and quality of working life, New Technology, Work and Employment, 23(3), 151-166.

Deakin, S., Hobbs, R., Konzellman, S. and Wilkinson, F. (2004) 'Working corporations: corporate governance and innovation in Labour-Management Partnerships in Britain' in M. Stuart and M. Martinez-Lucio (eds). Partnership and Modernisation in Employment Relations. London: Routledge, pp. 104-135.

Dietz, G. 'Partnership and the development of trust in British workplaces, Human Resource Management Journal, Vol. 14, No. 1, 2004. pp5-24.

Dietz, G., Cullen, J., Coad, A. (2005) 'Can there be non-union forms of workplace partnership?', Employee Relations, 27 (3), 289-306.

DTI. (1998) Fairness at work, Cmnd 3968. London: DTI.

Dundon, T., Rollinson, D. (2004) Employment Relations in Non-Union Firms". Routledge: London

Edwards, P. (2003) 'The Employment Relationship and the Field of Industrial Relations' in P. Edwards (ed). Industrial Relations: Theory and Practice. Oxford: Blackwell, pp. 1-36.

Gall G. (2004) 'Trade union recognition in Britain 1995-2002: turning a corner?', Industrial Relations Journal, 35(3). pp249-270.

Gall, G. (2003) The meaning of militancy. London: Ashgate.

Gollan, P.J. (2007) Employee representation in non-union firms. London: Sage.

Guest D. and Peccei R. (2001) 'Partnership at work: mutuality and the balance of advantage', British Journal of Industrial Relations, 39 (2) pp207-236.

Guest, D. Brown, W. Peccei, R. and Huxley, K. (2008) Does partnership at work increase trust? An analysis based on the 2004 Workplace Employment Relations Survey, Industrial Relations Journal, 39(2), pp.124-152.

Hall, P. and Soskice, D. (Eds) (2001) Varieties of Capitalism, OUP, Oxford.

Haynes P. and Allen M. 'Partnership as a union strategy: a preliminary evaluation, Employee Relations, Vol. 23, No. 2, 2001. pp. 164-87.

Heaton, N., Mason, B. and Morgan, J. (2002) 'Partnership and multi-unionism in the Health Service', Industrial Relations Journal, 33(2).

Heery E. (2002) 'Partnership versus organising: alternative futures for British trade unionism', Industrial Relations Journal, 33 (1), pp20-35. 
Heery, E., Conley, H., Delbridge, R. and Stewart, P. (2004) 'Seeking partnership for the contingent workforce' in M. Martinez-Lucio and M. Stuart (eds). Partnership and modernisation in employment relations. London: Routledge, pp. 274-302.

Howell, C. (1999) 'Unforgiven: British Trade Unionism in Crisis' in G. Ross and A. Martin (eds). The Brave New World of Labor: European Trade Unions at the Millennium. New York: Berghahn, pp. 26-74.

Hyman, R. (1978) Pluralism, procedural consensus and collective bargaining, British Journal of Industrial Relations, 16, 16-40.

Hyman, R. (2004) 'Whose (social) partnership' in M. Stuart and M. Martinez-Lucio (eds). Partnership and modernisation in employment relations. London: Routledge, pp. 386-411.

Ichniowski, C. Kochan, T. Levine, D. Olson, C. and Strauss, G. (1996) What works at work: overview and assessment, Industrial Relations, 35(3), 299-353.

IOD (2002) The DTI: Past problems, current difficulties and future objectives. London: IOD.

IPA. (1997) Towards industrial partnership. London: IPA.

IPA (2004) Abbey Case Study, IPA Case Study, May.

IPA (2005) Moving partnership on: a final report. London: IPA/Unions 21.

IRS. (1999) 'Partnership Delivers the Goods at Tesco', IRS Employment Trends, 686 4-9.

Jenkins, J. (2007) Gambling partners? The risky outcomes of workplace partnership, Work Employment and Society, 21(4), 635-662.

Jenkins, J. (2008) 'Pressurised partnership: a case of perishable compromise in contested terrain, New Technology, Work and Employment, 23(3), 167-180.

Johnstone, S., Wilkinson, A. and Ackers, P. (2004) 'Partnership paradoxes: A case study of an energy company', Employee Relations, 26 (4), 353-376.

Johnstone, S. (2009) Labour and management co-operation: workplace partnership in UK financial services, Gower.

Kelly, J. (1996) 'Union militancy and social partnership' in P. Ackers, C. Smith and C. Smith (eds). The new workplace and trade unionism. London: Routledge, .

Kelly, J. (2000) The limits and contradictions of social partnership, Communist Review, 22, pp.37.

Kelly J. (2004a) 'Social partnership arrangements in Britain', Industrial Relations, 43(1), pp 267292. 
Kelly, J. (2004b) 'Social partnership agreements in Britain' in M. Stuart and M. Martinez-Lucio (eds). Partnership and the modernisation of employment relations. London: Palgrave, pp. 303-332.

Kersely, B. Alpen, C. and Forth, J. Bryson, A. Bewley, H. Dix, H. And Oxenbridge, S. (2006) Inside the workplace: findings from the 2004 Workplace Employment Relations Survey. London: Routledge.

Kochan, T. and Osterman, P. (1994) The Mutual Gains Enterprise: forging a winning partnership among labor, management and government. Boston, MA: Harvard Business School.

Kochan, T. Adler, P. McKersie, R. Eaton, A. Segal, P. and Gerhart, P. (2008) The potential and precariousness of partnership: the case of the Kaiser Permanente Labour Management Partnership, Industrial Relations, 47(1), pp.36-66.

Knell, J. (1999) Partnership at work? Employment Relations Research Series. London: DTI.

Marchington, M. (1998) 'Partnership in context: towards a European model Human Resource Management: the New Agenda' in P. Sparrow and M. Marchington (eds). London: FT Pitman,

Marchington, M., Goodman, J., Wilkinson, A. and Ackers, P. (1992) New developments in employee involvement. Sheffield: Employment Department Research 2.

Marchington, M., Wilkinson, A., Ackers, P. and Goodman, J. (1994) 'Understanding the meaning of participation: views from the workplace', Human Relations, 47 (8), 867-894.

Marchington, M. Wilkinson. A. Ackers, P. And Dundon, T. (2001) Management choice and employee voice. London: CIPD.

Marchington, M. and Wilkinson, A. (2008) Human resource management at work: people management and development, CIPD, London.

Marks, A. Finlay, P. Hine, J. McKinlay, A. and Thompson, P. (1998) The politics of partnership? Innovation in employment relations in the Scottish spirit industry, British Journal of Industrial Relations, 36(2) p.209.

Martin, A. and Ross, G. (1999) The Brave New World of European Labour, European Trade Unions at the Millennium. New York: Berghan Books.

Mason, B. Heaton, N. And Morgan, J. (2004) Social partnership strategies in two health service trusts, Personnel Review, 33(6), 648-664.

Martínez-Lucio, M. and Stuart, M. (2005) "Partnership'and new industrial relations in a risk society: an age of shotgun weddings and marriages of convenience', Work, Employment \& Society, 19 (4), 797-817. 
Martinez-Lucio M. and Stuart. M. 'Assessing partnership: the prospects for, and challenges of, modernisation', Employee Relations, Vol. 24, No. 3, 2002. pp252-261

Martinez-Lucio, M. and Stuart, M. (2004) 'Swimming against the tide: social partnership, mutual gains and the revival of 'tired' HRM', International Journal of Human Resource Management, 15 (2), 410.

McBride, J. and Stirling, J. (2002) 'Partnership and process in the maritime construction industry', Employee Relations, 24 (3), 290.

Metcalf, D. (2004) 'British Unions: Resurgence or Perdition?', Centre for Economic Performance, Mimeo.

Oxenbridge, S. And Brown, W. (2002) The two faces of partnership? An assessment of partnership and co-operative employer/trade unions relationships, Employee Relations, 24(3), pp.262-276.

Oxenbridge S. and Brown W. (2004a) 'Developing partnership relationships: a case of leveraging power', in M. Stuart and M. Martinez-Lucio (eds), Partnership and Modernisation in Employment Relations. London, Routledge.

Oxenbridge, S. and Brown, W. (2004b) 'Developing partnership relationships: a case of leveraging power' in Partnership and Modernisation in Employment Relations. London: Routledge, pp. 136-189.

Oxenbridge, S. and Brown, W. (2004c) 'A Poisoned Chalice? Trade Union Representatives in Partnership and Co-operative Employer-Union Relationships' in G. Healy, E. Heery, P. Taylor and W. Brown (eds). The future of worker representation. London: Routledge, pp. 187-206.

Richardson, M., Stewart, P., Danford, A., Tailby, S. and Upchurch, M. (2004) 'Employees' experience of workplace partnership in the private and public sector' in M. Stuart and M. Martinez-Lucio (eds). Partnership and modernisation in employment relations. London: Routledge, pp. 333-355.

Richardson, M., Tailby, S., Danford, A., Stewart, P. and Upchurch, M. (2005) 'Best value and workplace partnership in local government', Personnel Review, 34 (6), 713-728.

Roper, I. (2000) 'Quality management and trade unions in local government', Employee Relations, 22 (5), 442-466.

Samuel, P. J. (2005) 'Partnership working and the cultivated activist', Industrial Relations Journal, 36 (1), 59-76.

Samuel, P.J. (2007) Partnership consultation and employer domination in two British life and pension firms, Work Employment and Society, 21(3), p.459. 
Sisson, K. (1999) The 'new' European social model, Employee Relations, 21(5), 445-462.

Smith, C. Child, J. Rowlinson, M. (1990) Reshaping work: The Cadbury Experience, New York: Cambridge University Press.

Stuart, M. and Martinez-Lucio, M. (2004a) Partnership and Modernisation in Employment Relations. London: Routledge.

Stuart, M. and Martinez-Lucio, M. (2004b) 'Where next for partnership?' in M. Stuart and M. Martinez-Lucio (eds). Partnership and modernisation in employment relations. London: Routledge, pp. 412-424.

Suff, R. and Williams, S. (2004) 'The myth of mutuality? Employee perceptions of partnership at Borg Warner', Employee Relations, 26 (1), 30-43.

Tailby, S., Richardson, M., Stewart, P., Danford, A. and Upchurch, M. (2004) 'Partnership at work and worker participation: an NHS case study', Industrial Relations Journal, 35 (5), 403-418.

Taylor, P. and Ramsey, H. (1998) 'Unions partnership and HRM: sleeping with the enemy?', International Journal of Employment Studies, 6 (2), 115-143.

Terry M. ' Can 'partnership' reverse the decline of British trade unions?' (2003) Work Employment and Society,17 (3) pp 459-472.

Terry, M. (1999) 'Systems of collective employee representation in non-union firms in the UK', Industrial Relations Journal, 30 (1), 16-30.

Terry, M. And Smith, J. Evaluation of Partnership at Work Fund. Employment Relations Research No.17. London: DTI.

TUC. (1999) Partners for progress: next steps for the new unionism. London: TUC.

TUC (2002) Partnership works. London: TUC.

TUC. (2003) TUC High Performance Workplaces. London: TUC.

Turnbull, P., Blyton, P. and Harvey, G. (2004) 'Cleared for Take-off? Management-Labour Partnership in the European Civil Aviation Industry', European Journal of Industrial Relations, 10 (3), 287-307.

Undy, R. (1999) Annual Review Article: New Labour's Industrial Settlement: The third way? British Journal of Industrial Relations, 37(2), 315-336.

Upchurch, M. Danford, A. Tailby, S. And Richardson, M. (2008) The Realities of Partnership at Work, London: Palgrave.

Waddington, J. (2003) 'Trade union organisation' in P. Edwards (ed). Industrial relations: theory and practice. Oxford: Blackwell, pp. 214-256. 
Walton, R.E. and McKersie, R.B. (1965) A behavioural theory of labor negotiations, London: McGraw Hill.

Wills, J. (2004) 'Trade unionism and partnership in practice: evidence from the Barclays-Unifi agreement', Industrial Relations Journal, 35 (4), 329-343.

Wray, D. (2004) 'Management and union motives in the negotiation of partnership: a case study of the process and outcome at an Engineering Company' in M. Stuart and M. MartinezLucio (eds). Partnership and Modernisation in Employment Relations. London: Routledge, pp. 190-215.

Yin, R. K. (2003) Case Study Research: Design and Methods. London: Sage Publications. 
Figure 1:

Defining partnership: the TUC and IPA

\begin{tabular}{|c|c|c|c|}
\hline Partnership element & IPA & TUC & Classification \\
\hline $\begin{array}{l}\text { A joint declaration of commitment to } \\
\text { organisational success }\end{array}$ & $\mathrm{Y}$ & $\mathrm{Y}$ & $\begin{array}{c}\text { Values } \\
\text { (Marchington, } \\
\text { 1998) } \\
\text { Commitment } \\
\text { (IPA, 1997) } \\
\end{array}$ \\
\hline $\begin{array}{l}\text { Mutual recognition of the legitimate role and } \\
\text { interests of management, employees and } \\
\text { trade unions where present }\end{array}$ & $\mathrm{Y}$ & $\mathrm{Y}$ & $\begin{array}{c}\text { Values } \\
\text { (Marchington, } \\
\text { 1998) } \\
\text { Commitment } \\
\text { (IPA, 1997) } \\
\end{array}$ \\
\hline $\begin{array}{l}\text { Commitment and effort to develop and sustain } \\
\text { trust between the organisation's constituencies }\end{array}$ & $\mathrm{Y}$ & Implicit & $\begin{array}{c}\text { Values } \\
\text { (Marchington, } \\
\text { 1998) } \\
\text { Commitment } \\
\text { (IPA, 1997) } \\
\end{array}$ \\
\hline $\begin{array}{l}\text { Means for sharing information } \\
\text { [IPA]/Transparency [TUC] }\end{array}$ & $\mathrm{Y}$ & $\mathrm{Y}$ & Process \\
\hline $\begin{array}{l}\text { Consultation and employee involvement, with } \\
\text { representative arrangements for an } \\
\text { 'independent employee voice' } \\
\text { [IPA]/Transparency [TUC] }\end{array}$ & $\mathrm{Y}$ & $\mathrm{Y}$ & Process \\
\hline $\begin{array}{l}\text { Policies to balance flexibility with employment } \\
\text { security [IPA/TUC] }\end{array}$ & $\mathrm{Y}$ & $\mathrm{Y}$ & Outcome \\
\hline Sharing organisational success [IPA] & $\mathrm{Y}$ & - & Outcome \\
\hline Adding value [TUC] & Implicit & $\mathrm{Y}$ & Outcome \\
\hline Improving the quality of working life [TUC] & Implicit & $\mathrm{Y}$ & Outcome \\
\hline
\end{tabular}

Figure 2:

Partnership: polarised perspectives

\begin{tabular}{|c|c|}
\hline Optimistic & Pessimistic \\
\hline $\begin{array}{l}\text { - Union renewal, legitimacy, } \\
\text { renaissance, organisation } \\
\text { - } \quad \text { Organisational success, } \\
\text { competitiveness, productivity } \\
\text { - Employee involvement, quality of } \\
\text { working life } \\
\text { - } \quad \text { Win-win } \\
\text { - } \quad \text { Greater job security } \\
\text { - } \quad \text { Higher working conditions } \\
\text { - }\end{array}$ & $\begin{array}{l}\text { - Union incorporation, emasculation } \\
\text { - } \quad \text { Work intensification } \\
\text { - } \text { Surveillance } \\
\text { - } \text { Co-option } \\
\text { - Employee disillusionment } \\
\text { Zero-sum }\end{array}$ \\
\hline $\begin{array}{l}\text { Ackers and Payne (1998) IPA (2005), } \\
\text { TUC (1999,2002) }\end{array}$ & $\begin{array}{l}\text { Kelly (1996; 2000); Claydon (1998); Gal } \\
(2003)\end{array}$ \\
\hline
\end{tabular}


Figure 3:

Empirical partnership studies in the UK 1998-2008

\begin{tabular}{|c|c|c|c|c|c|}
\hline & AUTHORS & SECTOR & METHOD & FOCUS & TU STATUS \\
\hline 1 & $\begin{array}{l}\text { Ackers et.al } \\
2004\end{array}$ & VARIOUS & $\begin{array}{l}\text { CASE } \\
\text { STUDY }\end{array}$ & EMPLOYEE VOICE & $\begin{array}{c}\text { UNION/ } \\
\text { NON-UNION }\end{array}$ \\
\hline 2 & $\begin{array}{l}\text { Bacon and } \\
\text { Storey, } 2000\end{array}$ & VARIOUS & $\begin{array}{l}\text { CASE } \\
\text { STUDY }\end{array}$ & $\begin{array}{l}\text { MANAGEMENT } \\
\text { STRATEGY }\end{array}$ & UNION \\
\hline 3 & $\begin{array}{l}\text { Badigannavar } \\
\text { and Kelly, } \\
2004\end{array}$ & CIVIL SERVICE & $\begin{array}{l}\text { CASE } \\
\text { STUDY }\end{array}$ & $\begin{array}{c}\text { UNION } \\
\text { ORGANISATION }\end{array}$ & UNION \\
\hline 4 & $\begin{array}{l}\text { Badigannavar } \\
\text { and Kelly, } \\
2005\end{array}$ & RETAIL & $\begin{array}{l}\text { CASE } \\
\text { STUDY }\end{array}$ & $\begin{array}{l}\text { EMPLOYEE } \\
\text { OUTCOMES }\end{array}$ & NON-UNION \\
\hline 5 & Beale, 2004 & INLAND REVENUE & $\begin{array}{l}\text { CASE } \\
\text { STUDY }\end{array}$ & $\begin{array}{c}\text { HISTORICAL } \\
\text { DEVELOPMENT }\end{array}$ & UNION \\
\hline 6 & $\begin{array}{l}\text { Danford et.al } \\
2004\end{array}$ & AEROSPACE & $\begin{array}{l}\text { CASE } \\
\text { STUDY }\end{array}$ & EMPLOYEE VOICE & UNION \\
\hline 7 & $\begin{array}{l}\text { Danford et.al } \\
2005\end{array}$ & AEROSPACE & $\begin{array}{l}\text { CASE } \\
\text { STUDY }\end{array}$ & $\begin{array}{l}\text { EMPLOYEE } \\
\text { RESPONSES }\end{array}$ & UNION \\
\hline 8 & $\begin{array}{l}\text { Danford et.al } \\
2008\end{array}$ & VARIOUS & $\begin{array}{l}\text { CASE } \\
\text { STUDY }\end{array}$ & $\begin{array}{l}\text { EMPLOYEE } \\
\text { EXPERIENCE }\end{array}$ & $\begin{array}{l}\text { UNION/NON- } \\
\text { UNION }\end{array}$ \\
\hline 9 & $\begin{array}{l}\text { Deakin et.al } \\
2004\end{array}$ & VARIOUS & $\begin{array}{l}\text { CASE } \\
\text { STUDY }\end{array}$ & $\begin{array}{l}\text { CORPORATE } \\
\text { GOVERNANCE }\end{array}$ & UNION \\
\hline 10 & $\begin{array}{l}\text { Dietz et.al } \\
2005\end{array}$ & CLOTHING & $\begin{array}{l}\text { CASE } \\
\text { STUDY }\end{array}$ & $\begin{array}{l}\text { NON-UNION } \\
\text { PARTNERSHIP }\end{array}$ & NON-UNION \\
\hline 11 & Dietz 2004 & $\begin{array}{c}\text { SPIRITS, } \\
\text { ENGINEERING NHS }\end{array}$ & $\begin{array}{l}\text { CASE } \\
\text { STUDY }\end{array}$ & $\begin{array}{c}\text { PARTNERSHIP AND } \\
\text { TRUST }\end{array}$ & UNION \\
\hline 12 & Gall 2001 & FINANCE & $\begin{array}{c}\text { UNION } \\
\text { INTERVIEWS }\end{array}$ & IR DEVELOPMENT & UNION \\
\hline 13 & $\begin{array}{l}\text { Guest and } \\
\text { Peccei } 2001\end{array}$ & VARIOUS & SURVEY & MUTUALITY & UNION \\
\hline 14 & $\begin{array}{l}\text { Haynes and } \\
\text { Allen } 2001\end{array}$ & $\begin{array}{l}\text { RETAIL/ } \\
\text { FINANCE }\end{array}$ & $\begin{array}{l}\text { CASE } \\
\text { STUDY }\end{array}$ & UNION STRATEGY & UNION \\
\hline 15 & $\begin{array}{l}\text { Heaton et.al } \\
2000\end{array}$ & NHS & $\begin{array}{l}\text { CASE } \\
\text { STUDY }\end{array}$ & $\begin{array}{c}\text { UNION } \\
\text { RELATIONSHIPS }\end{array}$ & UNION \\
\hline 16 & $\begin{array}{l}\text { Heery et.al } \\
2004\end{array}$ & MANPOWER/TGWU & $\begin{array}{l}\text { CASE } \\
\text { STUDY }\end{array}$ & TRADE UNIONISM & UNION \\
\hline 17 & Jenkins, 2007 & AUTOMOTIVE & $\begin{array}{l}\text { CASE } \\
\text { STUDY }\end{array}$ & UNIONS/OUTCOMES & UNION \\
\hline 18 & Jenkins, 2008 & MANUFACTURING & $\begin{array}{l}\text { CASE } \\
\text { STUDY }\end{array}$ & $\begin{array}{c}\text { WORK } \\
\text { ORGANISATION }\end{array}$ & UNION \\
\hline 19 & $\begin{array}{l}\text { Johnstone } \\
\text { et.al } 2004\end{array}$ & UTILITIES & $\begin{array}{c}\text { CASE } \\
\text { STUDY } \\
\end{array}$ & ACTOR REACTIONS & UNION \\
\hline 20 & Kelly, 2004a & VARIOUS & $\begin{array}{l}\text { SECONDARY } \\
\text { ANALYSIS }\end{array}$ & LABOUR OUTCOMES & UNION \\
\hline 21 & Kelly, 2004b & VARIOUS & $\begin{array}{l}\text { SECONDARY } \\
\text { ANALYSIS }\end{array}$ & LABOUR OUTCOMES & UNION \\
\hline 22 & $\begin{array}{l}\text { Marchington } \\
\text { et.al, } 2001\end{array}$ & VARIOUS & $\begin{array}{l}\text { CASE } \\
\text { STUDY }\end{array}$ & EMPLOYEE VOICE & $\begin{array}{c}\text { UNION/ } \\
\text { NON-UNION }\end{array}$ \\
\hline 23 & $\begin{array}{l}\text { Marks et.al, } \\
1998\end{array}$ & SPIRITS & $\begin{array}{l}\text { CASE } \\
\text { STUDY }\end{array}$ & $\begin{array}{c}\text { WORKPLACE } \\
\text { CHANGE/INNOVATION }\end{array}$ & UNION \\
\hline 24 & $\begin{array}{l}\text { Martin et.al, } \\
2003\end{array}$ & OFFSHORE OIL & $\begin{array}{l}\text { CASE } \\
\text { STUDY }\end{array}$ & $\begin{array}{l}\text { MANAGEMENT AND } \\
\text { UNION STRATEGIES }\end{array}$ & UNION \\
\hline
\end{tabular}




\begin{tabular}{|c|c|c|c|c|c|}
\hline 25 & $\begin{array}{l}\text { Martinez- } \\
\text { Lucio and } \\
\text { Stuart, } 2002\end{array}$ & MSF & SURVEY & $\begin{array}{c}\text { TU REPRESENTATIVE } \\
\text { ATTITUDES }\end{array}$ & UNION \\
\hline 26 & $\begin{array}{l}\text { Mason et.al, } \\
2004\end{array}$ & $\mathrm{NHS}$ & $\begin{array}{l}\text { CASE } \\
\text { STUDY }\end{array}$ & $\begin{array}{l}\text { MANAGEMENT AND } \\
\text { UNION STRATEGIES }\end{array}$ & UNION \\
\hline 27 & $\begin{array}{l}\text { McBride and } \\
\text { Stirling, } 2002\end{array}$ & $\begin{array}{c}\text { MARITIME } \\
\text { CONSTRUCTION }\end{array}$ & $\begin{array}{l}\text { CASE } \\
\text { STUDY }\end{array}$ & $\begin{array}{c}\text { TU REPRESENTATIVE } \\
\text { EXPERIENCES }\end{array}$ & UNION \\
\hline 28 & $\begin{array}{l}\text { Oxenbridge } \\
\text { and Brown, } \\
2002\end{array}$ & VARIOUS & $\begin{array}{l}\text { CASE } \\
\text { STUDY }\end{array}$ & $\begin{array}{l}\text { CHARACTERISTICS } \\
\text { OF PARTNERSHIP }\end{array}$ & UNION \\
\hline 29 & $\begin{array}{l}\text { Oxenbridge } \\
\text { and Brown, } \\
2004 b\end{array}$ & VARIOUS & $\begin{array}{l}\text { CASE } \\
\text { STUDY }\end{array}$ & $\begin{array}{c}\text { FORMAL AND } \\
\text { INFORMAL } \\
\text { PARTNERSHIPS }\end{array}$ & UNION \\
\hline 30 & $\begin{array}{l}\text { Oxenbridge } \\
\text { and Brown, } \\
2004 a\end{array}$ & VARIOUS & $\begin{array}{l}\text { CASE } \\
\text { STUDY }\end{array}$ & $\begin{array}{l}\text { STABILITY OF } \\
\text { PARTNERSHIP }\end{array}$ & UNION \\
\hline 31 & $\begin{array}{l}\text { Richardson } \\
\text { et.al } 2004\end{array}$ & $\begin{array}{c}\text { AEROSPACE/LOCAL } \\
\text { GVT }\end{array}$ & $\begin{array}{l}\text { CASE } \\
\text { STUDY }\end{array}$ & $\begin{array}{l}\text { EMPLOYEE } \\
\text { RESPONSES }\end{array}$ & UNION \\
\hline 32 & $\begin{array}{l}\text { Richardson } \\
\text { et.al, } 2005\end{array}$ & $\begin{array}{c}\text { LOCAL } \\
\text { GOVERNMENT }\end{array}$ & $\begin{array}{l}\text { CASE } \\
\text { STUDY }\end{array}$ & $\begin{array}{c}\text { EMPLOYEE } \\
\text { EXPERIENCES }\end{array}$ & UNION \\
\hline 33 & Samuel, 2005 & FINANCE & $\begin{array}{l}\text { CASE } \\
\text { STUDY }\end{array}$ & $\begin{array}{l}\text { UNION WORKPLACE } \\
\text { ORGANISATION }\end{array}$ & UNION \\
\hline 34 & Samuel, 2007 & FINANCE & $\begin{array}{l}\text { CASE } \\
\text { STUDY }\end{array}$ & CONSULTATION & UNION \\
\hline 35 & $\begin{array}{l}\text { Stuart and } \\
\text { Martinez } \\
\text { Lucio, 2004c }\end{array}$ & MSF UNION & SURVEY & $\begin{array}{l}\text { RISKS AND TRADE } \\
\text { UNIONISTS }\end{array}$ & UNION \\
\hline 36 & $\begin{array}{l}\text { Suff and } \\
\text { Williams, } \\
2004\end{array}$ & VEHICLE PARTS & $\begin{array}{l}\text { CASE } \\
\text { STUDY }\end{array}$ & $\begin{array}{c}\text { EMPLOYEE } \\
\text { PERCEPTIONS }\end{array}$ & UNION \\
\hline 37 & $\begin{array}{l}\text { Tailby et.al, } \\
2004\end{array}$ & NHS & CASESTUDY & UNION STRATEGY & UNION \\
\hline 38 & $\begin{array}{l}\text { Taylor and } \\
\text { Ramsey, } \\
1998\end{array}$ & RETAIL & $\begin{array}{l}\text { CASE } \\
\text { STUDY }\end{array}$ & $\begin{array}{l}\text { HRM \& TRADE } \\
\text { UNIONS }\end{array}$ & UNION \\
\hline 39 & $\begin{array}{l}\text { Turnbull et.al, } \\
2004\end{array}$ & AVIATION & $\begin{array}{c}\text { CASE } \\
\text { STUDY \& } \\
\text { SURVEY }\end{array}$ & $\begin{array}{l}\text { INSTITUTIONAL } \\
\text { CONTEXT }\end{array}$ & UNION \\
\hline 40 & $\begin{array}{l}\text { Upchurch } \\
\text { et.al, } 2008\end{array}$ & VARIOUS & $\begin{array}{l}\text { CASE } \\
\text { STUDY }\end{array}$ & MUTUALITY & $\begin{array}{l}\text { UNION/NON- } \\
\text { UNION }\end{array}$ \\
\hline 41 & Wills, 2004 & FINANCE & $\begin{array}{l}\text { CASE } \\
\text { STUDY }\end{array}$ & $\begin{array}{l}\text { TRADE UNION } \\
\text { ORGANISATION }\end{array}$ & UNION \\
\hline 42 & Wray 2004 & ENGINEERING & $\begin{array}{l}\text { CASE } \\
\text { STUDY }\end{array}$ & $\begin{array}{l}\text { PARTNERSHIP } \\
\text { AGREEMENT } \\
\text { NEGOTIATIONS }\end{array}$ & UNION \\
\hline
\end{tabular}

Figure 4 


\begin{tabular}{l|l}
\hline Positive & Negative \\
\hline Genuine & Counterfeit \\
Nurturing & Containing \\
Robust & Shallow \\
Labour-parity & Employer-dominant \\
Mature and enduring & Weak and disintegrating \\
Offensive & Defensive \\
Nurturing & Transitional \\
Nurturing & Coerced/ Transitional \\
\hline
\end{tabular}

Figure 5

Sensitivity to different forms of partnership arrangement

\begin{tabular}{l|l}
\hline \multicolumn{2}{c}{ Partnership arrangements } \\
\hline De facto & De jure \\
Informal & Formal \\
Union & Non-union \\
Buoyant markets & Struggling markets \\
Crisis & Natural evolution \\
Public sector & Private sector \\
\hline
\end{tabular}

